\title{
Cytokine-Leukotriene Receptor Interactions
}

\author{
Marek Rola-Pleszczynski^ and Jana Stankova \\ Immunology Division, Department of Pediatrics, Faculty of Medicine, Université de \\ Sherbrooke, Sherbrooke QC, J1H 5N4 Canada \\ E-mails: marek.rola-pleszczynski@usherbrooke.ca; jana.stankova@usherbrooke.ca
}

Received January 22, 2007; Revised June 12, 2007; Accepted July 2, 2007; Published September 1, 2007

Biochemical and pharmacological studies have identified the structure of leukotrienes, the pathways that lead to their synthesis, and the signaling events they trigger when they interact with their cognate receptors. A privileged interaction exists between these lipid mediators and another group of molecules essential for inflammation and immune modulation, namely, cytokines. Whereas leukotrienes can trigger the synthesis and release of selected cytokines in distinct cell populations, many cytokines can affect cellular responsiveness to leukotrienes by modulating leukotriene receptor expression. As we progressively begin to unravel these complex interactions, new areas of cell-cell communication and eventual therapeutic interventions will emerge.

KEYWORDS: leukotriene, lipid mediator, receptor, G-protein coupled receptor, arachidonic acid, cytokine, interleukin, interferon, growth factor, signaling

Receptors for leukotriene (LT) $\mathrm{B}_{4}\left(\mathrm{BLT}_{1}\right.$ and $\left.\mathrm{BLT}_{2}\right)$ and for the cysteinyl-LTs $\left(\mathrm{CysLT}_{1}\right.$ and $\left.\mathrm{CysLT}_{2}\right)$ had been studied pharmacologically for almost 2 decades before they were cloned and structurally characterized. In this paper, we will review how leukotrienes can modulate cytokine production through their interaction with selective receptors and, conversely, how various cytokines can regulate the expression of leukotriene receptors and thus affect cellular responsiveness to leukotrienes.

\section{MODULATION OF CYTOKINE PRODUCTION BY LEUKOTRIENE RECEPTOR ACTIVATION}

\section{Leukotriene $\mathrm{B}_{4}$}

Soon after the discovery of leukotrienes by Borgeat and Samuelsson[1,2], LTB $_{4}$ was found to modulate the immune response by inducing suppressor cells and by enhancing natural cytotoxic activity in lymphocytes[3,4,5]. $\mathrm{LTB}_{4}$ was also shown to stimulate the production of interleukin (IL)-2, interferon (IFN) $\gamma$, and IL- 5 by T cells[6,7,8,9] (Table 1 ).

$\mathrm{LTB}_{4}$ stimulation of human monocytes was found to activate gene transcription, namely, that of the transcription factors c-fos and c-jun[10]. Moreover, $\mathrm{LTB}_{4}$ could induce the transcriptional activation of the IL-6 gene and enhance IL-6 production in monocytes[11,12]. Macrophages stimulated with plateletactivating factor (PAF) produced increased amounts of IL-6 and TNF $\alpha$, both of which were dependent on endogenous leukotriene production[13]. 
TABLE 1

Leukotriene-Induced Modulation of Cytokine Expression

\begin{tabular}{|c|c|c|c|c|}
\hline Leukotriene & Cytokine & Effect* & Target Cells & Ref. \\
\hline \multirow[t]{11}{*}{$\mathrm{LTB}_{4}$} & IL-2 & + & T lymphocytes & [7] \\
\hline & $\mathrm{IFN} \gamma$ & + & T lymphocytes & {$[6,7,8]$} \\
\hline & IL-5 & + & T lymphocytes & [9] \\
\hline & IL-6 & + & Monocytes, macrophages & {$[11,12]$} \\
\hline & TNF $\alpha$ & + & Alveolar macrophages & [13] \\
\hline & MCP-1 & + & Monocytes & [16] \\
\hline & IL-8 & + & PMN & [17] \\
\hline & IL-10 & + & Dendritic cells (mouse) & [19] \\
\hline & IL-2R $\alpha$ & + & Monocytes & [15] \\
\hline & $\mathrm{IL}-2 \mathrm{R} \beta$ & + & Monocytes, NK cells & {$[14,15]$} \\
\hline & LIF & + & BM stromal cells & [18] \\
\hline \multirow[t]{10}{*}{$\mathrm{LTC}_{4}, \mathrm{LTD}_{4}$} & IL-8 & + & Monocytes, dendritic cells, endothelial cells, mast cells & {$[20,31,32]$} \\
\hline & MCP-1 & + & Monocytes, THP-1 cells & {$[21,22]$} \\
\hline & RANTES & + & Lung mononuclear cells & [23] \\
\hline & MIP-1 $\beta$ & + & Alveolar macrophages, mast cells & {$[24,30]$} \\
\hline & IL-1 $\beta$ & + & Vascular smooth muscle cells & [29] \\
\hline & TNF $\alpha$ & + & Alveolar macrophage, mast cells & {$[24,30]$} \\
\hline & IL-4 & + & Eosinophils & {$[33,34]$} \\
\hline & IL-5 & + & Mast cells & [30] \\
\hline & IL-10 & + & Dendritic cells & [35] \\
\hline & TGF $\beta$ & + & Eosinophils, airway epithelial cells & {$[25,26,28]$} \\
\hline
\end{tabular}

* The plus (+) sign indicates augmentation of production of the corresponding cytokine.

Human natural killer (NK) cells can be activated by IL-2. $\mathrm{LTB}_{4}$ was found to up-regulate the expression of the $\beta$ chain of the IL-2 receptor, thus rendering the cells more responsive to the stimulatory effects of IL-2[14]. NK cells pre-exposed to $\mathrm{LTB}_{4}$ became more cytotoxic to target cells when treated with IL-2 than unexposed NK cells.

Resting monocytes do not express the $\alpha$ chain of the IL-2 receptor complex. $\mathrm{LTB}_{4}$ was shown to induce the expression of IL-2R $\alpha$ and to augment the expression of IL-2R $\beta$ in human monocytes[15], thus allowing the cells to express the heterotrimeric, high-affinity IL-2 receptor complex. LTB $_{4}$-pretreated monocytes were thus rendered more sensitive to IL-2 and consequently produced greater amounts of TNF $\alpha$ in response to lower concentrations of IL-2.

$\mathrm{LTB}_{4}$ was also found to up-regulate the expression of monocyte chemoattractant protein-1 (MCP-1) in monocytes[16] and IL-8 in neutrophils[17].

$\mathrm{LTB}_{4}$ was reported to induce leukemia inhibitory factor (LIF), but not IL-6 production by human bone marrow stromal cells[18]. In murine bone marrow-derived dendritic cells, $\mathrm{LTB}_{4}$ enhanced LPSstimulated IL-10 release by approximately $40 \%$ and inhibited IL-12 p40 release by approximately $20 \%[19]$. Both effects were mediated by the high-affinity BLT $_{1}$ receptor. 


\section{Cysteinyl-Leukotrienes}

Because cysteinyl-leukotrienes (CysLTs) are major protagonists in the pathophysiology of human asthma, and because neutrophils are involved in the more severe form of asthma, we studied the potential for $\mathrm{LTD}_{4}$ to induce synthesis of the chemokine IL-8 through activation of the CysLT 1 receptor. We found $\mathrm{LTD}_{4}$ to induce IL-8 gene expression in monocytic THP-1 cells and human dendritic cells with complete abrogation by selective CysLT $T_{1}$ antagonists[20]. Human embryonic kidney (HEK)-293 cells stably transfected with CysLT $T_{1}$ were used to further study the transcriptional regulation of the IL-8 promoter. Stimulation of the cells with graded concentrations of $\mathrm{LTD}_{4}$ resulted in a time- and concentrationdependent induction of IL-8 transcription and protein synthesis. Use of IL-8 promoter mutants with substitutions in their NF- $\mathrm{BB}$, activator protein (AP)-1, and NF-IL-6 binding elements revealed a requirement for NF- $\mathrm{BB}$ and AP-1, but not NF-IL-6, in LTD $_{4}$-induced activation of the IL-8 promoter.

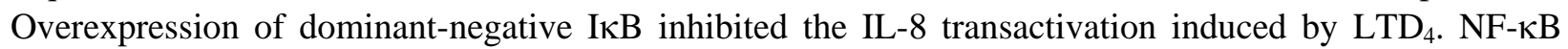
DNA binding activity was induced by $\mathrm{LTD}_{4}$, as determined by electrophoretic mobility shift assays, and could be supershifted by antibodies against p50 and p65. Supershift assays after LTD $_{4}$ stimulation also indicated the formation of a c-Jun/c-Fos complex. Moreover, our results demonstrate that $\mathrm{LTD}_{4}$ upregulates the expression of c-fos and $c$-jun at the mRNA level. Our data showed for the first time that $\mathrm{LTD}_{4}$, via the CysLT1 receptor, could transcriptionally activate IL-8 production, with involvement of the transcription factors p50, p65, Fos, and Jun. These findings provide mechanistic and potentially therapeutic elements for modulation of the inflammatory component of asthma.

In this context, CysLTs have been reported to induce the production of other chemokines, such as monocyte chemoattractant protein (MCP)-1 in human monocytes/macrophages[21,22] and Regulated upon Activation, Normal T-cell Expressed, and Secreted (RANTES) in a murine model of asthma[23]. In a rat alveolar macrophage line, $\mathrm{LTD}_{4}$ enhanced mRNA and protein expression of MIP-1 $\alpha$ and TNF $\alpha$ induced by LPS[24].

CysLTs have also been shown to induce or augment the expression of TGF $\beta$ in eosinophils and airway epithelial cells[25,26]. We have recently confirmed these findings and extended them to show that $\mathrm{LTD}_{4}$-induced TGF $\beta$ can synergize with fibroblast-growth factor- 2 to induce bronchial smooth muscle cell proliferation[27,28]. This further suggests a mechanism for the airway remodeling potential of CysLTs. The latter may also be involved in inflammatory phenomena within the vessel wall. Indeed, in vascular smooth muscle cells, $\mathrm{LTD}_{4}$ was found to induce IL-1 $\beta$ production[29], suggesting that it may play a role in the pathogenesis of atherosclerosis.

IL-4-primed mast cells were shown to secrete IL-5, TNF $\alpha$, and MIP-1 $\beta$ when stimulated with either $\mathrm{LTC}_{4}$ or $\mathrm{LTD}_{4}$ [30]. Moreover, the CysLT 1 antagonist MK571 significantly attenuated the generation of IL-5 and TNF $\alpha$ by mast cells activated by FceRI cross-linkage[30], suggesting that endogenous CysLTs

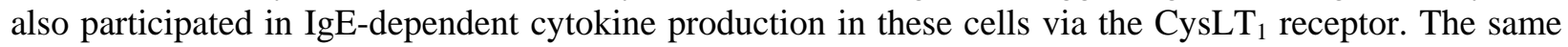
group also indicated that IL-8 secretion was stimulated by $\mathrm{LTC}_{4}$ and $\mathrm{LTD}_{4}$ in IL-4-primed mast cells (although no baseline IL-8 production was shown)[31]. In contrast to the other cytokines, however, IL-8 secretion was reportedly resistant to blockade by MK571, suggesting dependence on the CysLT 2 receptor for LT-induced mast cell production of this cytokine. We have also recently shown that $\mathrm{LTC}_{4}$, more than $\mathrm{LTD}_{4}$, could induce IL-8 production in endothelial cells, expressing exclusively CysLT 2 [32]. Moreover, in cells stably transfected with $\mathrm{CysLT}_{2}, \mathrm{LTC}_{4}$ induced IL-8 promoter transactivation, which was dependent on AP-1 and NF- $\mathrm{BB}$ transcription factors and which involved PKC $\delta$ and $\varepsilon$ signaling, respectively.

LTC $_{4}$ was shown to induce IL-4 production in cord blood eosinophils[33] and to induce IL-4 release from blood eosinophils through an intracrine mechanism[34]. CysLTs were also found to regulate dendritic cell functions in a murine model of asthma and to modulate the production of IL-10 and IL-5 in the lungs[35]. Conversely, the CysLT $\mathrm{T}_{1}$ antagonist pranlukast was shown to inhibit IL-5 production in rats[36] and guinea pigs[37] in models of antigen-dependent late asthmatic response. Pranlukast was also 
shown to attenuate allergen-specific $\mathrm{TNF} \alpha$ production and NF- $\mathrm{B}$ translocation in monocytes of asthmatic patients[38].

Of note, some effects of CysLT $T_{1}$ antagonists have been shown to be independent of their receptor antagonist activity, especially at higher concentrations. Thus, they can modulate iNOS function[39], reduce IL-5 production[40], and inhibit NF-אB activation[41].

\section{MODULATION OF LEUKOTRIENE RECEPTOR EXPRESSION BY CYTOKINES}

Since the level of expression of receptors for inflammatory mediators may directly affect the degree of responsiveness of cells to these mediators, we and others have studied the potential for modulation of leukotriene receptor expression by biological response modifiers, including cytokines.

\section{$\mathrm{BLT}_{1}$}

Although TNF $\alpha$ was reported to modulate the affinity state of the $\mathrm{LTB}_{4}$ receptor in human PMN[42], the expression of the high-affinity receptor for $\mathrm{LTB}_{4}\left(\mathrm{BLT}_{1}\right)$ has been found to be relatively resistant to regulation. When they characterized the promoter region of the $\mathrm{BLT}_{1}$ gene, Kato and colleagues[43] found that it contains cis-elements mainly associated with basal expression, such as SP1, which was found to be a major activator of basal transcription of $\mathrm{BLT}_{1}$. The promoter region of the $\mathrm{BLT}_{1}$ gene includes the open reading frame (ORF) of the $\mathrm{BLT}_{2}$ gene, which encodes a low-affinity receptor for $\mathrm{LTB}_{4}[44]$. BLT${ }_{1}$ is predominantly expressed on leukocytes and endothelial cells. Interestingly, the CpG sites of the $\mathrm{BLT}_{1}$ promoter region are highly methylated in $\mathrm{BLT}_{1}$-nonexpressing cells, but not methylated in $\mathrm{BLT}_{1}$-expressing cells. Furthermore, methylation of this region in vitro inhibited the promoter activity of the BLT 1 gene. Thus, methylation at $\mathrm{CpG}$ sites in the promoter region is important for cell-specific transcription of $\mathrm{BLT}_{1}$.

We have shown $\mathrm{BLT}_{1}$ expression in human neutrophils to be up-regulated by the corticosteroid dexamethasone (DEX)[45] (Table 2). DEX up-regulated the steady-state levels of BLT 1 mRNA in human neutrophils in a time- and concentration-dependent manner. The effect was dependent on transcriptional activity, whereas $\mathrm{BLT}_{1}$ mRNA stability was not affected. DEX-induced up-regulation of $\mathrm{BLT}_{1}$ expression was prevented by pretreatment with the $\mathrm{LTB}_{4}$ antagonist LY 255283. Moreover, $\mathrm{LTB}_{4}$ itself up-regulated the expression of $\mathrm{BLT}_{1}$ mRNA. BLT 1 protein expression on neutrophils exposed to DEX for $24 \mathrm{~h}$ was also up-regulated two- to threefold, and DEX-treated as well as $\mathrm{LTB}_{4}$-treated cells showed enhanced responsiveness to $\mathrm{LTB}_{4}$ in terms of intracellular $\mathrm{Ca}^{++}$mobilization and chemotaxis. Whereas DEX and $\mathrm{LTB}_{4}$ alone decreased neutrophil apoptosis by approximately $50 \%$, neutrophils treated with both $\mathrm{LTB}_{4}$ and DEX showed greater than $90 \%$ survival at $24 \mathrm{~h}$. Moreover, $\mathrm{BLT}_{1}$ antagonists prevented the increased neutrophil survival induced by DEX as well as by $\mathrm{LTB}_{4}$. Taken together, our results suggest that DEXinduced up-regulation of $\mathrm{BLT}_{1}$ expression in neutrophils may be one mechanism through which glucocorticoids can prolong neutrophil survival, namely, by enhancing cell responses to the antiapoptotic effect of $\mathrm{LTB}_{4}$.

Pettersson and colleagues[46] reported that proinflammatory mediators, such as IFN $\gamma$, TNF $\alpha$, and LPS, down-regulated BLT $\mathrm{B}_{1}$ expression in monocytes, whereas the anti-inflammatory cytokine, IL-10, and DEX up-regulated BLT 1 expression. The effect of IFN $\gamma$ appeared to be exerted through a block in transcriptional activity. Receptor down-modulation following IFN $\gamma$ stimulation resulted in a diminished chemotactic response to $\mathrm{LTB}_{4}$. In our hands, however, $\mathrm{BLT}_{1}$ expression in monocytes, macrophages, or neutrophils was unaffected by any of a number of stimuli, including the bacterial products LPS and formyl-methionyl-leucyl-phenylalanine, or the cytokines IL-1 $\beta$, TNF $\alpha$, IL-4, IL-6, IL-10, or GM-CSF (unpublished observations). 
TABLE 2

Cytokine-Induced Modulation of Leukotriene Receptor Expression

\begin{tabular}{|c|c|c|c|c|}
\hline $\begin{array}{l}\text { Leukotriene } \\
\text { Receptor }\end{array}$ & Cytokine & Effect* & Target Cell & Ref. \\
\hline \multirow[t]{6}{*}{$\mathrm{BLT}_{1}$} & IL-1 $\beta$ & + & Endothelial cells & [47] \\
\hline & TNF $\alpha$ & Weak & Endothelial cells & {$[47]$} \\
\hline & &,- or 0 & Monocytes & [46], MR-P, unpublished \\
\hline & IL-10 &,+ or 0 & Monocytes & [46], MR-P, unpublished \\
\hline & $\mathrm{IFN \gamma}$ &,- or 0 & Monocytes & [46], MR-P, unpublished \\
\hline & SCF & - & Mast cells & [48] \\
\hline \multirow[t]{3}{*}{$\mathrm{BLT}_{2}$} & $\mathrm{TNF} \alpha$ & + & Endothelial cells & [47] \\
\hline & $\mathrm{IL}-1 \beta$ & + & Endothelial cells & [47] \\
\hline & SCF & - & Mast cells & [48] \\
\hline \multirow[t]{8}{*}{ CysLT $_{1}$} & IL-5 & + & Eosinophilic HL-60 cells & [52] \\
\hline & IL-4 & + & $\begin{array}{l}\text { Monocytes, macrophages; B and T } \\
\text { lymphocytes }\end{array}$ & {$[54,55,60]$} \\
\hline & & 0 & Mast cells & [56] \\
\hline & & 0 & Bronchial smooth muscle cells & [57] \\
\hline & IL-13 & + & $\begin{array}{l}\text { Monocytes, macrophages; bronchial } \\
\text { smooth muscle cells; fibroblasts; } \\
\text { eosinophils }\end{array}$ & {$[54,55,57,59]$} \\
\hline & $\mathrm{IFN \gamma}$ & + & Bronchial smooth muscle cells & {$[57,58]$} \\
\hline & & - & Macrophages (inhibits IL-4 effect) & MR-P, unpublished \\
\hline & TGF $\beta$ & + & Bronchial smooth muscle cells & {$[57]$} \\
\hline \multirow[t]{7}{*}{$\mathrm{CysLT}_{2}$} & IL-4 & + & $\begin{array}{l}\text { Mast cells; T and B lymphocytes; } \\
\text { eosinophils }\end{array}$ & {$[31,54]$} \\
\hline & & 0 & Eosinophils & [63] \\
\hline & $\mathrm{IFN \gamma}$ & + & $\begin{array}{l}\text { Eosinophils; endothelial cells; monocytes; } \\
\text { T and B lymphocytes }\end{array}$ & {$[54,63,64]$} \\
\hline & & 0 & Bronchial smooth muscle cells & [57] \\
\hline & IL-13 & + & Eosinophils & [54] \\
\hline & & 0 & Bronchial smooth muscle cells, eosinophils & {$[57,63]$} \\
\hline & TGF $\beta$ & 0 & Bronchial smooth muscle cells & [57] \\
\hline
\end{tabular}

* The plus (+) sign indicates augmentation of receptor expression in the indicated cells by the corresponding cytokine, whereas the negative (-) or zero (0) sign indicates reduction of expression or no effect, respectively.

On the other hand, endothelial cells, which normally express very little BLT $T_{1}$, were recently shown to express $\mathrm{BLT}_{1}$ in response to LPS, $\mathrm{LTB}_{4}$, and IL-1 [47]. Moreover, stem cell factor was shown to inhibit $\mathrm{BLT}_{1}$ mRNA expression in murine bone marrow-derived mast cells and reduce their migration to $\mathrm{LTB}_{4}[48]$.

\section{$\mathrm{BLT}_{2}$}

$\mathrm{BLT}_{2}$, which binds $\mathrm{LTB}_{4}$ with a lower affinity, is expressed ubiquitously, in contrast to BLT $\mathrm{T}_{1}$. Since its open reading frame is located in the promoter region of the $\mathrm{BLT}_{1}$ gene, it is suggested that there may be shared transcriptional regulation of these two receptors[44]. Very little information is available on the 
modulation of $\mathrm{BLT}_{2}$ expression. Treatment of human umbilical vein endothelial cells with LPS leads to a greater than tenfold increase in the levels of BLT 1 mRNA without any significant effects on BLT $_{2}$ mRNA[47]. TNF $\alpha$ increases the expression of $\mathrm{BLT}_{2}$ mRNA approximately six times above basal levels with only a modest increase in BLT $T_{1}$ mRNA. IL-1 $\beta$ causes variable and parallel increases of both BLT and $\mathrm{BLT}_{2}$ mRNA. On the other hand, stem cell factor was found to reduce $\mathrm{BLT}_{2}$ (and $\mathrm{BLT}_{1}$ ) mRNA expression in murine bone marrow-derived mast cells[48].

In conclusion, although $\mathrm{LTB}_{4}$ can modulate the production of a number of cytokines and thus appear to play an important role in inflammation and immune defenses, the expression of its receptors is relatively resistant to modulation by cytokines or other biological modifiers. This allows BLT $_{1}$-expressing cells to maintain a consistent responsiveness to $\mathrm{LTB}_{4}$ with relative independence from environmental influences.

\section{CysLT $_{1}$}

CysLT $_{1}$ expression in healthy individuals appears to be fairly restricted to leukocytes and bronchial smooth muscle cells (BSMC)[49,50]. During inflammation, however, other cells, e.g., bronchial epithelial cells, have also been found to express CysLT $_{1}[51]$.

Modulation of CysLT 1 expression was first demonstrated using the cytokine IL-5[52]. We had previously shown that HL-60 cells differentiated toward the eosinophilic lineage (HL-60/eos) developed specific functional $\mathrm{LTD}_{4}$ receptors[53]. Work was then undertaken to study the potential modulation of CysLT $_{1}$ expression in HL-60/eos by IL-5, an important regulator of eosinophil function. IL-5 could rapidly up-regulate $\mathrm{CysLT}_{1}$ mRNA expression, with consequently enhanced $\mathrm{CysLT}_{1}$ protein expression and function in HL-60/eos. CysLT 1 mRNA expression was augmented two- to 15-fold following treatment with IL-5. The effect was seen after $2 \mathrm{~h}$, was maximal by $8 \mathrm{~h}$, and maintained at $24 \mathrm{~h}$. Although CysLT $_{1}$ mRNA was constitutively expressed in undifferentiated HL-60 cells, its expression was not modulated by IL-5 in the absence of differentiation. Differentiated HL-60/eos cells pretreated with IL-5 for $24 \mathrm{~h}$ showed enhanced CysLT $\mathrm{T}_{1}$ expression on the cell surface, as assessed by flow cytometry using a polyclonal anti-CysLT 1 antibody. They also showed enhanced responsiveness to LTD4, but not to $\mathrm{LTB}_{4}$ or PAF, in terms of $\mathrm{Ca}^{++}$mobilization, and augmented chemotactic response to LTD4. Recently, Early

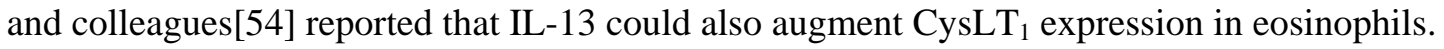

In a subsequent study, we also reported that the Th2 cytokine IL-13 could upregulate CysLT mRNA $_{1}$ levels, with consequently enhanced CysLT $\mathrm{T}_{1}$ protein expression and function in human monocytes and monocyte-derived macrophages[55]. CysLT 1 mRNA expression was augmented two- to fivefold following treatment with IL-13 and was due to enhanced transcriptional activity. The effect was observed after $4 \mathrm{~h}$, was maximal by $8 \mathrm{~h}$, and maintained at $24 \mathrm{~h}$. IL-4, but not IFN $\gamma$, induced a similar pattern of

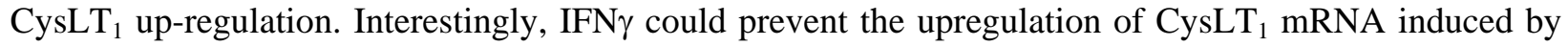
IL-4 or IL-13.

Monocytes pretreated with IL-13 or IL-4 for $24 \mathrm{~h}$ also showed enhanced CysLT $\mathrm{T}_{1}$ protein expression, as assessed by flow cytometry using a polyclonal anti-CysLT ${ }_{1}$ antibody[55]. They also showed enhanced responsiveness to LTD4, but not to $\mathrm{LTB}_{4}$, in terms of $\mathrm{Ca}^{++}$mobilization, as well as augmented chemotactic activity. These studies suggested a possible mechanism by which IL-5, IL-13, and IL-4 could modulate CysLT $_{1}$ expression on eosinophils, monocytes, and macrophages, and consequently their responsiveness to $\mathrm{LTD}_{4}$, and thus contribute to the pathogenesis of asthma and allergic diseases. Woszczek and colleagues[22] confirmed our findings with IL-4 and determined the activation of a STAT6 responsive element in the CysLT 1 promoter by IL-4. Interestingly, treating cord blood-derived mast cells with IL-4 did not alter CysLT ${ }_{1}$ receptor mRNA or cell surface protein expression[56].

Airway remodeling is a feature of chronic asthma and involves a number of structural changes, including BSMC hyperplasia and hypertrophy. CysLTs have been suggested to play a role in airway remodeling in addition to their numerous other physiopathological effects. In a subsequent study[57], we 
aimed at characterizing the potential modulation by cytokines of CysLT $_{1}$ receptor expression in BSMC and the eventual functional relevance of this modulation. When human BSMC were exposed to TGF $\beta$, IL-13, or IFN $\gamma$, their expression of CysLT $T_{1}$ receptor was significantly augmented in a time- and concentration-dependent manner. The positive effect of IFN $\gamma$ on BSMC proliferation was also reported by Amrani and colleagues[58]. Interestingly, IL-4 had no significant effect on $\mathrm{CysLT}_{1}$ receptor expression in

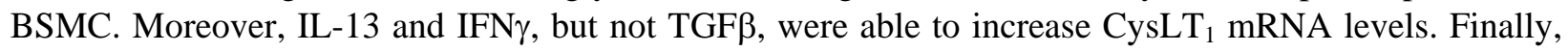
when BSMC were pretreated with TGF $\beta$ or IL-13, but not IFN $\gamma$, their responsiveness to $\mathrm{LTD}_{4}$ was markedly enhanced in terms of BSMC proliferation. Whereas TGF $\beta$, IL-13, or $\mathrm{LTD}_{4}$ alone had little effect on BSMC proliferation, pre-exposure of the cells to TGF $\beta$ or IL-13 for 24 h resulted in a significant increase in proliferation in response to $\mathrm{LTD}_{4}$. The enhanced proliferation was totally prevented by pretreating the cytokine-primed BSMC with the selective $\mathrm{CysLT}_{1}$ receptor antagonist, montelukast. Taken together, these findings indicated a synergy between certain cytokines and CysLTs, mediated by the augmented expression of the CysLT $\mathrm{T}_{1}$ receptor and subsequent $\mathrm{LTD}_{4}$-triggered BSMC proliferation. IL-13 was also found to augment CysLT $T_{1}$ expression in fibroblasts[59]. These findings support a role for CysLTs in the airway remodeling observed in asthmatic patients and may provide a rationale for preventive and therapeutic intervention.

We also found that B lymphocytes expressed CysLT $_{1}$ at both the mRNA and protein levels. Moreover, a two- to threefold enhancement of CysLT $_{1}$ expression was observed following B-cell exposure to a combination of activating anti-CD40 antibody and IL-4[60]. The expression of CysLT was $_{1}$ also enhanced when B lymphocytes were cocultured with CD154-transfected fibroblasts in the presence of IL-4. Moreover, IL-4 and CD40-activated B lymphocytes showed an increased responsiveness to $\mathrm{LTD}_{4}$ in terms of cytosolic calcium flux, which was totally prevented by the selective CysLT $_{1}$ antagonist montelukast. Stimulation of IL-4 and CD40-activated B lymphocytes with picomolar concentrations of $\mathrm{LTD}_{4}$ induced mature epsilon transcripts and up-regulated immunoglobulin (Ig)E and IgG production two- to threefold. Expression of CysLT $_{1}$ could thus be up-regulated in B lymphocytes following stimulation with CD154 and IL-4, with consequent increased responsiveness of the cells to $\mathrm{LTD}_{4}$ in terms of Ig production. Early and colleagues[54] also recently reported that IL-4 could enhance CysLT ${ }_{1}$ expression in B cells as well as T cells.

Dendritic cells (DCs) acquire, during their maturation, the expression of the chemokine receptor CCR7 and the ability to migrate to lymph nodes in response to CC chemokine ligand 19 (CCL19). This migration is impaired in mice lacking the $\mathrm{LTC}_{4}$ transporter and restored by addition of exogenous $\mathrm{LTC}_{4}$. To define the role of LT in human DC function, we studied the expression and function of the CysLT receptors during DC differentiation from monocytes and subsequent maturation[61]. Maturation of DC with LPS, a classic Toll-like receptor 4 agonist, reduced CysLT ${ }_{1}$ expression by $50 \%$, whereas CysLT $_{2}$ expression was increased. In contrast, the Toll-like receptor 3 agonist poly inosinic and cytidylic acid (polyI:C) had no effect on CysLT $_{1}$ or CysLT $_{2}$ receptor expression. Down-regulation of CysLT $_{1}$ expression by LPS could not be mimicked by TNF $\alpha$ alone or in combination with IL-1 $\beta$ or IL-6. It was, however, prevented by inhibitors of COX and could be reproduced by a combination of TNF $\alpha$ and prostaglandin $\mathrm{E}_{2}$. Immature DCs and DCs matured with polyI:C, but not with LPS, responded to $\mathrm{LTD}_{4}$ with a robust cytosolic calcium flux, which was prevented by the CysLT 1 antagonist montelukast. LTD $_{4}$ induced DC chemotaxis and enhanced DC migration in response to CCL19 in DCs matured with polyI:C, but only weakly in DCs matured with LPS. Our data suggest that human DCs may differentially respond to leukotriene, depending on their maturational stimuli.

Interestingly, $\mathrm{LTD}_{4}$ priming of immature DC enhanced IL-4 production more than IFN $\gamma$ production by naïve $\mathrm{CD}^{+} \mathrm{CD} 45 \mathrm{RA}{ }^{+} \mathrm{T}$ cells, with a twofold increase at $1 \mathrm{nM} \mathrm{LTD} 4$. Similarly, $\mathrm{LTD}_{4}$ priming of poly I:C-matured DC enhanced IL-4 production by naïve T cells fourfold. In contrast, LPS-matured DC were not affected by $\mathrm{LTD}_{4}$ priming in inducing T-cell production of either IL-4 or IFN $\gamma$ (unpublished observations). 


\section{CysLT $_{2}$}

CysLT $_{2}$ is coexpressed with CysLT $T_{1}$ on most leukocytes, including neutrophils, eosinophils, basophils, mast cells, monocytes, macrophages, DCs, and B lymphocytes. It is also expressed in the absence of CysLT $_{1}$ in a number of cell types, including vascular smooth muscle cells and endothelial cells, heart Purkinje-conducting fiber cells, cardiomyocytes, and adrenal chromaffin cells[62].

CysLT $_{2}$ expression was shown to be modestly up-regulated by IL-4 in mast cells[31]. It was also upregulated by IFN $\gamma$, but not by IL-1 $\beta$, IL-4, IL-5, IL-13, or TNF $\alpha$, in eosinophils from asthmatic patients[63]. However, we reported that $\mathrm{CysLT}_{2}$ expression levels were not increased in human bronchial smooth muscle cells by IL-4, IL-13, TGF $\beta$, or IFN $\gamma$ [57]. Recently, Woszczek and colleagues[64] reported that IFN $\gamma$ could up-regulate $\mathrm{CysLT}_{2}$ expression in human endothelial cells with enhanced responsiveness of the cells to CysLTs. As with CysLT 1, CysLT $_{2}$ expression appears to be controlled differently in each cell type.

In conclusion, a number of cytokines can modulate the expression of $\mathrm{CysLT}_{1}$ and/or $\mathrm{CysLT}_{2}$ in different cell populations. This is in contrast to the receptors for $\mathrm{LTB}_{4}$ and suggests that responsiveness of various cells to $\mathrm{LTC}_{4}$ and $\mathrm{LTD}_{4}$ may be quite dependent on environmental factors and subject to a finer degree of control.

Globally, as reviewed in this paper, LTs and cytokines are involved in a complex network of interactions, which appear to be ligand-, receptor-, and cell-specific. At this time, there are still very limited data available on the mechanisms and signaling pathways involved in the bidirectional modulation of cytokines and LTs. For instance, not all signaling by the G-protein coupled LT receptors is G-protein dependent. Moreover, several orthosteric receptor antagonists can act as inverse agonists and new allosteric ligands may provide precious tools to help understand LT receptor signaling. As we learn more about the interactions between LTs and cytokines, our understanding of this complex network should help us to devise more selective approaches for intervention in disease states where enhancement or reduction of lipid mediator and cytokine effects are sought.

\section{ACKNOWLEDGMENTS}

The authors' work was supported by grants from the Medical Research Council of Canada, the Canadian Institutes of Health Research, the National Cancer Institute of Canada, the Society for Cancer Research, the Foundation for Research into Children's Diseases, and by scholarships and studentships from the Canadian Institutes of Health Research and the Fonds de la recherche en santé du Québec. MR-P is the holder of a Canada Research Chair in Inflammation.

\section{REFERENCES}

1. Borgeat, P. and Samuelsson, B. (1979) Transformation of arachidonic acid by rabbit polymorphonuclear leukocytes. Formation of a novel dihydroxyeicosatetraenoic acid. J. Biol. Chem. 254, 2643-2646.

2. Borgeat, P. and Samuelsson, B. (1979) Arachidonic acid metabolism in polymorphonuclear leukocytes: unstable intermediate in formation of dihydroxy acids. Proc. Natl. Acad. Sci. U. S. A. 76, 3213-3217.

3. Rola-Pleszczynski, M., Borgeat, P., and Sirois, P. (1982) Leukotriene B4 induces human suppressor lymphocytes. Biochem. Biophys. Res. Commun. 108, 1531-1537.

4. Rola-Pleszczynski, M., Gagnon, L., and Sirois, P. (1983) Leukotriene B4 augments human natural cytotoxic cell activity. Biochem. Biophys. Res. Commun. 113, 531-537.

5. Payan, D.G. and Goetzl, E.J. (1983) Specific suppression of human T lymphocyte function by leukotriene B4. J. Immunol. 131, 551-553.

6. Rola-Pleszczynski, M., Bouvrette, L., Gingras, D., and Girard, M. (1987) Identification of interferon-gamma as the lymphokine that mediates leukotriene B4-induced immunoregulation. J. Immunol. 139, 513-517.

7. Rola-Pleszczynski, M., Chavaillaz, P.A., and Lemaire, I. (1986) Stimulation of interleukin 2 and interferon gamma production by leukotriene B4 in human lymphocyte cultures. Prostaglandins Leukot. Med. 23, 207-210. 
8. Johnson, H.M. and Torres, B.A. (1984) Leukotrienes: positive signals for regulation of gamma-interferon production. J. Immunol. 132, 413-416.

9. Yamaoka, K.A. and Kolb, J.P. (1993) Leukotriene B4 induces interleukin 5 generation from human T lymphocytes. Eur. J. Immunol. 23, 2392-2398.

10. Stankova, J. and Rola-Pleszczynski, M. (1992) Leukotriene B4 stimulates c-fos and c-jun gene transcription and AP-1 binding activity in human monocytes. Biochem. J. 282(Pt 3), 625-629.

11. Rola-Pleszczynski, M. and Stankova, J. (1992) Leukotriene B4 enhances interleukin-6 (IL-6) production and IL-6 messenger RNA accumulation in human monocytes in vitro: transcriptional and posttranscriptional mechanisms. Blood 80, 1004-1011.

12. Brach, M.A., de Vos, S., Arnold, C., Gruss, H.J., Mertelsmann, R., and Herrmann, F. (1992) Leukotriene B4 transcriptionally activates interleukin-6 expression involving NK-chi B and NF-IL6. Eur. J. Immunol. 22, $2705-2711$.

13. Thivierge, M. and Rola-Pleszczynski, M. (1994) Involvement of both cyclooxygenase and lipoxygenase pathways in platelet-activating factor-induced interleukin-6 production by alveolar macrophages. Ann. N. Y. Acad. Sci. 725, 213222.

14. Stankova, J., Gagnon, N., and Rola-Pleszczynski, M. (1992) Leukotriene B4 augments interleukin-2 receptor-beta (IL-2R beta) expression and IL-2R beta-mediated cytotoxic response in human peripheral blood lymphocytes. Immunology 76, 258-263.

15. Stankova, J., Dupuis, G., Gagnon, N., Thivierge, M., Turcotte, S., and Rola-Pleszczynski, M. (1993) Priming of human monocytes with leukotriene B4 enhances their sensitivity in IL-2-driven tumor necrosis factor-alpha production. Transcriptional and post-transcriptional up-regulation of IL-2 receptors. J. Immunol. 150, 4041-4051.

16. Huang, L., Zhao, A., Wong, F., Ayala, J.M., Struthers, M., Ujjainwalla, F., Wright, S.D., Springer, M.S., Evans, J., and Cui, J. (2004) Leukotriene B4 strongly increases monocyte chemoattractant protein-1 in human monocytes. Arterioscler. Thromb. Vasc. Biol. 24, 1783-1788.

17. McCain, R.W., Holden, E.P., Blackwell, T.R., and Christman, J.W. (1994) Leukotriene B4 stimulates human polymorphonuclear leukocytes to synthesize and release interleukin-8 in vitro. Am. J. Respir. Cell Mol. Biol. 10, 651657.

18. Denizot, Y., Trimoreau, F., and Praloran, V. (1998) Effects of lipid mediators on the synthesis of leukaemia inhibitory factor and interleukin 6 by human bone marrow stromal cells. Cytokine 10, 781-785.

19. Jozefowski, S., Biedron, R., Bobek, M., and Marcinkiewicz, J. (2005) Leukotrienes modulate cytokine release from dendritic cells. Immunology 116, 418-428.

20. Thompson, C., Cloutier, A., Bosse, Y., Thivierge, M., Le Gouill, C., Larivee, P., McDonald, P.P., Stankova, J., and Rola-Pleszczynski, M. (2006) CysLT1 receptor engagement induces AP-1- and NF-\{kappa\}B-dependent interleukin8 expression. Am. J. Respir. Cell Mol. Biol. 35, 697-704.

21. Ichiyama, T., Hasegawa, M., Ueno, Y., Makata, H., Matsubara, T., and Furukawa, S. (2005) Cysteinyl leukotrienes induce monocyte chemoattractant protein 1 in human monocytes/macrophages. Clin. Exp. Allergy 35, 1214-1219.

22. Woszczek, G., Pawliczak, R., Qi, H.Y., Nagineni, S., Alsaaty, S., Logun, C., and Shelhamer, J.H. (2005) Functional characterization of human cysteinyl leukotriene 1 receptor gene structure. J. Immunol. 175, 5152-5159.

Kawano, T., Matsuse, H., Kondo, Y., Machida, I., Saeki, S., Tomari, S., Mitsuta, K., Obase, Y., Fukushima, C., Shimoda, T., and Kohno, S. (2003) Cysteinyl leukotrienes induce nuclear factor kappa b activation and RANTES production in a murine model of asthma. J. Allergy Clin. Immunol. 112, 369-374.

24. Menard, G. and Bissonnette, E.Y. (2000) Priming of alveolar macrophages by leukotriene D(4): potentiation of inflammation. Am. J. Respir. Cell Mol. Biol. 23, 572-577.

25. Kato, Y., Fujisawa, T., Nishimori, H., Katsumata, H., Atsuta, J., Iguchi, K., and Kamiya, H. (2005) Leukotriene D4 induces production of transforming growth factor-beta1 by eosinophils. Int. Arch. Allergy Immunol. 137(Suppl 1), 17-20.

26. Perng, D.W., Wu, Y.C., Chang, K.T., Wu, M.T., Chiou, Y.C., Su, K.C., Perng, R.P., and Lee, Y.C. (2006) Leukotriene C4 induces TGF-beta1 production in airway epithelium via p38 kinase pathway. Am. J. Respir. Cell Mol. Biol. 34, 101-107.

27. Bosse, Y., Thompson, C., Stankova, J., and Rola-Pleszczynski, M. (2006) Fibroblast growth factor 2 and transforming growth factor beta1 synergism in human bronchial smooth muscle cell proliferation. Am. J. Respir. Cell Mol. Biol. 34, 746-753.

28. Bossé, Y., Thompson, C., McMahon, S., Dubois, C., Stankova, J., and Rola-Pleszczynski, M. Leukotriene D4induced, epithelial cell-derived transforming growth Factor b1 in human bronchial smooth muscle cell proliferation. Submitted

29.

Porreca, E., Conti, P., Feliciani, C., Di Febbo, C., Reale, M., Mincione, G., Neri, M., Amerio, P., and Cuccurullo, F. (1995) Cysteinyl-leukotriene D4 induced IL-1 beta expression and release in rat vascular smooth muscle cells. Atherosclerosis 115, 181-189.

30. Mellor, E.A., Austen, K.F., and Boyce, J.A. (2002) Cysteinyl leukotrienes and uridine diphosphate induce cytokine generation by human mast cells through an interleukin 4-regulated pathway that is inhibited by leukotriene receptor antagonists. J. Exp. Med. 195, 583-592.

31. Mellor, E.A., Frank, N., Soler, D., Hodge, M.R., Lora, J.M., Austen, K.F., and Boyce, J.A. (2003) Expression of the type 2 receptor for cysteinyl leukotrienes (CysLT2R) by human mast cells: functional distinction from CysLT1R. 
Proc. Natl. Acad. Sci. U. S. A. 100, 11589-11593.

32. Thompson, C., Cloutier, A., Bossé, Y., Poisson, C., Larivée, P., McDonald, P.P., Stankova, J., and Rola-Pleszczynski, M. (2007) Signaling by the cysteinyl-leukotriene receptor 2: involvement in chemokine gene transcription. J. Biol. Chem., in revision.

33. Bandeira-Melo, C., Hall, J.C., Penrose, J.F., and Weller, P.F. (2002) Cysteinyl leukotrienes induce IL-4 release from cord blood-derived human eosinophils. J. Allergy Clin. Immunol. 109, 975-979.

34. Bandeira-Melo, C., Woods, L.J., Phoofolo, M., and Weller, P.F. (2002) Intracrine cysteinyl leukotriene receptormediated signaling of eosinophil vesicular transport-mediated interleukin-4 secretion. J. Exp. Med. 196, 841-850.

35. Machida, I., Matsuse, H., Kondo, Y., Kawano, T., Saeki, S., Tomari, S., Obase, Y., Fukushima, C., and Kohno, S. (2004) Cysteinyl leukotrienes regulate dendritic cell functions in a murine model of asthma. J. Immunol. 172, 18331838.

36. Hojo, M., Suzuki, M., Maghni, K., Hamid, Q., Powell, W.S., and Martin, J.G. (2000) Role of cysteinyl leukotrienes in CD4(+) T cell-driven late allergic airway responses. J. Pharmacol. Exp. Ther. 293, 410-416.

37. Nabe, T., Yamashita, K., Miura, M., Kawai, T., and Kohno, S. (2002) Cysteinyl leukotriene-dependent interleukin-5 production leading to eosinophilia during late asthmatic response in guinea-pigs. Clin. Exp. Allergy 32, 633-640.

38. Tomari, S., Matsuse, H., Machida, I., Kondo, Y., Kawano, T., Obase, Y., Fukushima, C., Shimoda, T., and Kohno, S. (2003) Pranlukast, a cysteinyl leukotriene receptor 1 antagonist, attenuates allergen-specific tumour necrosis factor alpha production and nuclear factor kappa B nuclear translocation in peripheral blood monocytes from atopic asthmatics. Clin. Exp. Allergy 33, 795-801.

Offer, S., Shoseyov, D., Bibi, H., Eliraz, A., and Madar, Z. (2003) A leukotriene receptor antagonist modulates iNOS in the lung and in a leukotriene-free cell model. Nitric Oxide 9, 10-17.

40. Fukushima, C., Matsuse, H., Hishikawa, Y., Kondo, Y., Machida, I., Saeki, S., Kawano, T., Tomari, S., Obase, Y., Shimoda, T., Koji, T., and Kohno, S. (2005) Pranlukast, a leukotriene receptor antagonist, inhibits interleukin-5 production via a mechanism distinct from leukotriene receptor antagonism. Int. Arch. Allergy Immunol. 136, 165-172.

41. Ishinaga, H., Takeuchi, K., Kishioka, C., Suzuki, S., Basbaum, C., and Majima, Y. (2005) Pranlukast inhibits NFkappaB activation and MUC2 gene expression in cultured human epithelial cells. Pharmacology 73, 89-96.

42. Brom, J., Knoller, J., Koller, M., and Konig, W. (1988) Tumour necrosis factors modulate the affinity state of the leukotriene B4 receptor on human neutrophils. Immunology 65, 647-649.

43. Kato, K., Yokomizo, T., Izumi, T., and Shimizu, T. (2000) Cell-specific transcriptional regulation of human leukotriene B(4) receptor gene. J. Exp. Med. 192, 413-420.

44. Yokomizo, T., Kato, K., Terawaki, K., Izumi, T., and Shimizu, T. (2000) A second leukotriene B(4) receptor, BLT2. A new therapeutic target in inflammation and immunological disorders. J. Exp. Med. 192, 421-432.

45. Stankova, J., Turcotte, S., Harris, J., and Rola-Pleszczynski, M. (2002) Modulation of leukotriene B4 receptor-1 expression by dexamethasone: potential mechanism for enhanced neutrophil survival. J. Immunol. 168, 3570-3576. Pettersson, A., Sabirsh, A., Bristulf, J., Kidd-Ljunggren, K., Ljungberg, B., Owman, C., and Karlsson, U. (2005) Proand anti-inflammatory substances modulate expression of the leukotriene B4 receptor, BLT1, in human monocytes. $J$. Leukoc. Biol. 77, 1018-1025.

47. Qiu, H., Johansson, A.S., Sjostrom, M., Wan, M., Schroder, O., Palmblad, J., and Haeggstrom, J.Z. (2006) Differential induction of BLT receptor expression on human endothelial cells by lipopolysaccharide, cytokines, and leukotriene B4. Proc. Natl. Acad. Sci. U. S. A. 103, 6913-6918.

48. Lundeen, K.A., Sun, B., Karlsson, L., and Fourie, A.M. (2006) Leukotriene B4 receptors BLT1 and BLT2: expression and function in human and murine mast cells. J. Immunol. 177, 3439-3447.

49. $\quad$ Lynch, K.R., O'Neill, G.P., Liu, Q., Im, D.S., Sawyer, N., Metters, K.M., Coulombe, N., Abramovitz, M., Figueroa, D.J., Zeng, Z., Connolly, B.M., Bai, C., Austin, C.P., Chateauneuf, A., Stocco, R., Greig, G.M., Kargman, S., Hooks, S.B., Hosfield, E., Williams, D.L., Jr., Ford-Hutchinson, A.W., Caskey, C.T., and Evans, J.F. (1999) Characterization of the human cysteinyl leukotriene CysLT1 receptor. Nature 399, 789-793.

50. Figueroa, D.J., Breyer, R.M., Defoe, S.K., Kargman, S., Daugherty, B.L., Waldburger, K., Liu, Q., Clements, M., Zeng, Z., O'Neill, G.P., Jones, T.R., Lynch, K.R., Austin, C.P., and Evans, J.F. (2001) Expression of the cysteinyl leukotriene 1 receptor in normal human lung and peripheral blood leukocytes. Am. J. Respir. Crit. Care Med. 163, 226-233.

51. Z Zhu, J., Qiu, Y.S., Figueroa, D.J., Bandi, V., Galczenski, H., Hamada, K., Guntupalli, K.K., Evans, J.F., and Jeffery, P.K. (2005) Localization and upregulation of cysteinyl leukotriene-1 receptor in asthmatic bronchial mucosa. Am. J. Respir. Cell Mol. Biol. 33, 531-540.

52. Thivierge, M., Doty, M., Johnson, J., Stankova, J., and Rola-Pleszczynski, M. (2000) IL-5 up-regulates cysteinyl leukotriene 1 receptor expression in HL-60 cells differentiated into eosinophils. J. Immunol. 165, 5221-5226.

53. Patry, C., Muller, E., Laporte, J., Rola-Pleszczynski, M., Sirois, P., and de Brum-Fernandes, A.J. (1996) Leukotriene receptors in HL-60 cells differentiated into eosinophils, monocytes and neutrophils. Prostaglandins Leukot. Essent. Fatty Acids 54, 361-370.

54. $\quad$ Early, S.B., Barekzi, E., Negri, J., Hise, K., Borish, L., and Steinke, J.W. (2007) Concordant modulation of cysteinyl leukotriene receptor expression by IL-4 and IFN-\{gamma\} on peripheral immune cells. Am. J. Respir. Cell Mol. Biol. 36, 715-720.

55. Thivierge, M., Stankova, J., and Rola-Pleszczynski, M. (2001) IL-13 and IL-4 up-regulate cysteinyl leukotriene 1 
receptor expression in human monocytes and macrophages. J. Immunol. 167, 2855-2860.

56. Mellor, E.A., Maekawa, A., Austen, K.F., and Boyce, J.A. (2001) Cysteinyl leukotriene receptor 1 is also a pyrimidinergic receptor and is expressed by human mast cells. Proc. Natl. Acad. Sci. U. S. A. 98, 7964-7969.

57. Espinosa, K., Bosse, Y., Stankova, J., and Rola-Pleszczynski, M. (2003) CysLT1 receptor upregulation by TGF-beta and IL-13 is associated with bronchial smooth muscle cell proliferation in response to LTD4. J. Allergy Clin. Immunol. 111, 1032-1040.

58. Amrani, Y., Moore, P.E., Hoffman, R., Shore, S.A., and Panettieri, R.A., Jr. (2001) Interferon-gamma modulates cysteinyl leukotriene receptor-1 expression and function in human airway myocytes. Am. J. Respir. Crit. Care Med. 164, 2098-2101.

59. Chibana, K., Ishii, Y., Asakura, T., and Fukuda, T. (2003) Up-regulation of cysteinyl leukotriene 1 receptor by IL-13 enables human lung fibroblasts to respond to leukotriene C4 and produce eotaxin. J. Immunol. 170, 4290-4295.

60. Lamoureux, J., Stankova, J., and Rola-Pleszczynski, M. (2006) Leukotriene D4 enhances immunoglobulin production in CD40-activated human B lymphocytes. J. Allergy Clin. Immunol. 117, 924-930.

61. Thivierge, M., Stankova, J., and Rola-Pleszczynski, M. (2006) Toll-like receptor agonists differentially regulate cysteinyl-leukotriene receptor 1 expression and function in human dendritic cells. J. Allergy Clin. Immunol. 117, 1155-1162.

62. Heise, C.E., O'Dowd, B.F., Figueroa, D.J., Sawyer, N., Nguyen, T., Im, D.S., Stocco, R., Bellefeuille, J.N., Abramovitz, M., Cheng, R., Williams, D.L., Jr., Zeng, Z., Liu, Q., Ma, L., Clements, M.K., Coulombe, N., Liu, Y., Austin, C.P., George, S.R., O'Neill, G.P., Metters, K.M., Lynch, K.R., and Evans, J.F. (2000) Characterization of the human cysteinyl leukotriene 2 receptor. J. Biol. Chem. 275, 30531-30536.

63. Fujii, M., Tanaka, H., and Abe, S. (2005) Interferon-gamma up-regulates expression of cysteinyl leukotriene type 2 receptors on eosinophils in asthmatic patients. Chest 128, 3148-3155.

64. Woszczek, G., Chen, L.Y., Nagineni, S., Alsaaty, S., Harry, A., Logun, C., Pawliczak, R., and Shelhamer, J.H. (2007) IFN-gamma induces cysteinyl leukotriene receptor 2 expression and enhances the responsiveness of human endothelial cells to cysteinyl leukotrienes. J. Immunol. 178, 5262-5270.

\section{This article should be cited as follows:}

Rola-Pleszczynski, M. and Stankova, J. (2007) Cytokine-leukotriene receptor interactions. TheScientificWorldJOURNAL 7, 1348-1358. DOI 10.1100/tsw.2007.183. 

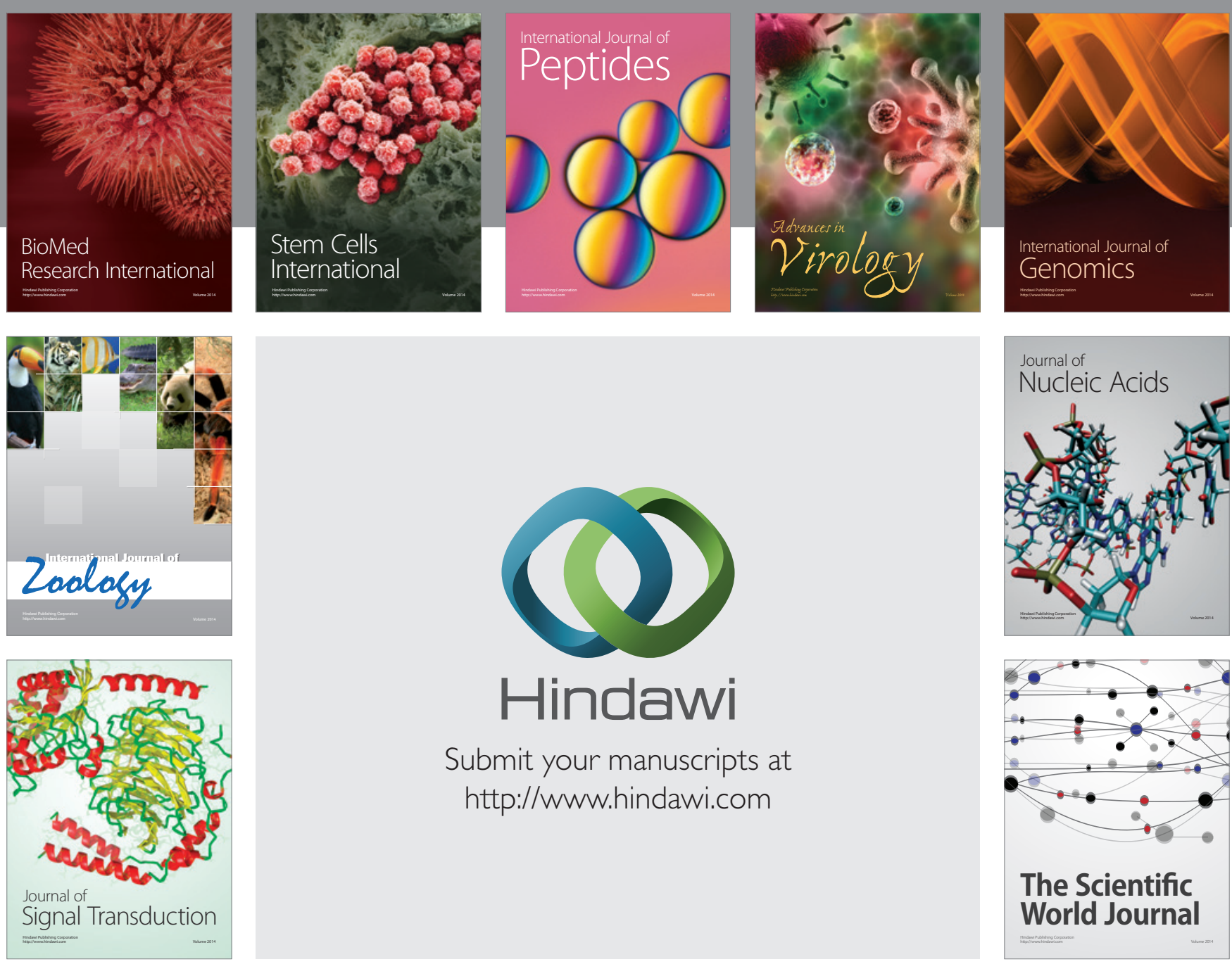

Submit your manuscripts at

http://www.hindawi.com
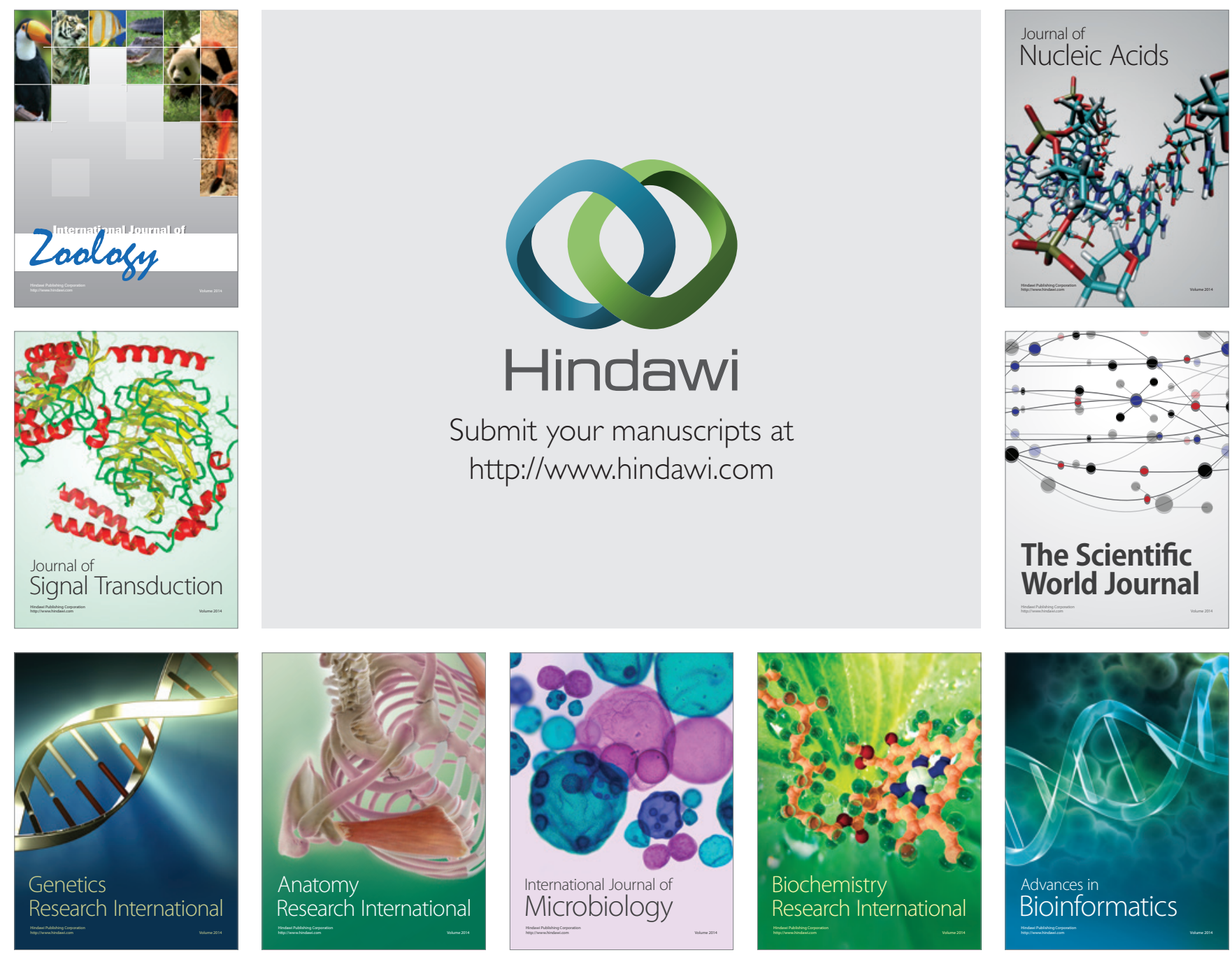

The Scientific World Journal
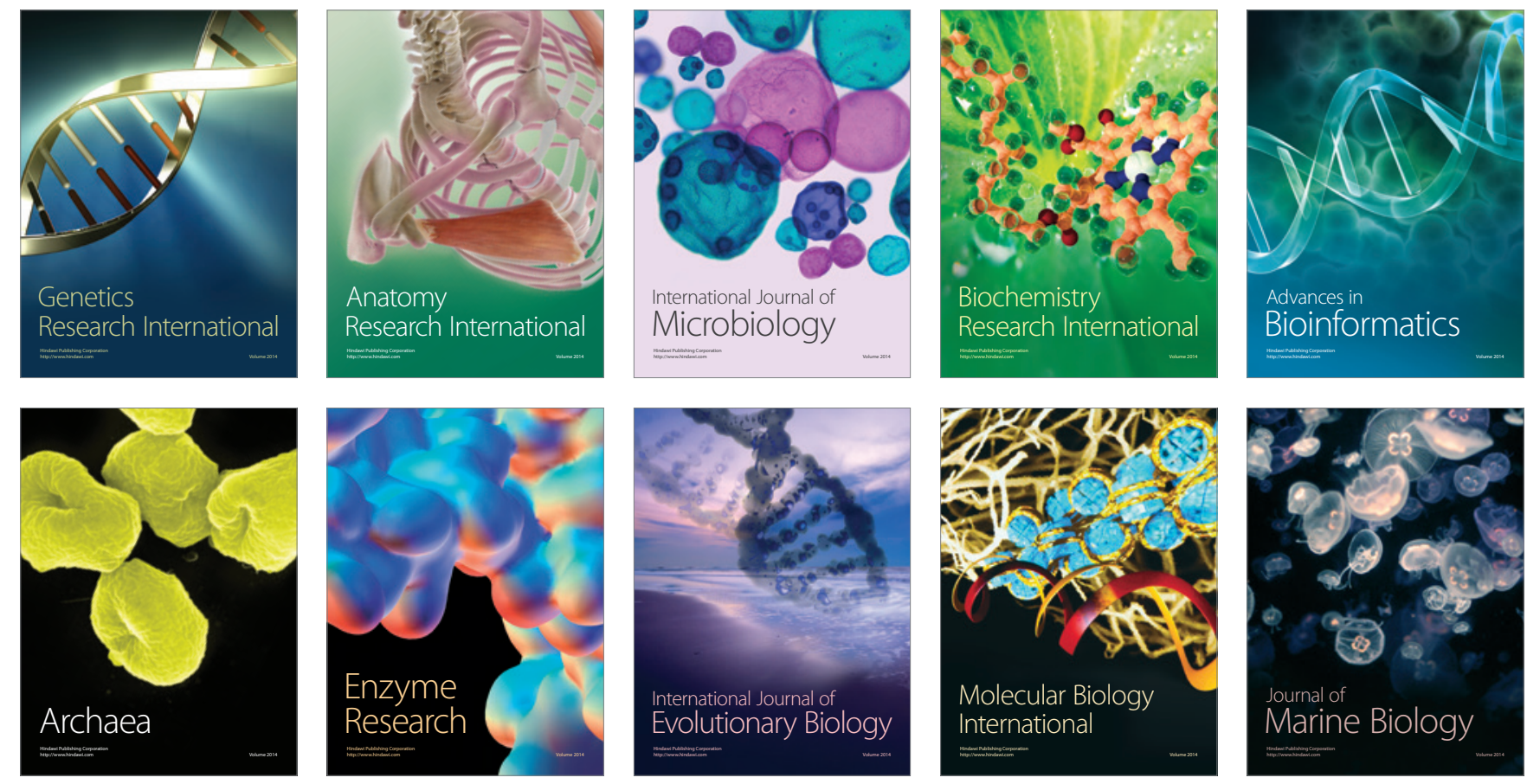